\title{
Neonatal mortality: the need for teaching strategies directed to the protection and promotion of children's health
}

\author{
Mortalidadle neonatal: a necessidlade de estratégias de ensino direcionadas a proteção e promoção \\ da saúde infantil \\ Mortalidad neonatal: la necesidad de estrategias didácticas dirigidas a la protección y promoción \\ de la salud del niñoTitle
}

Received: 01/18/2022 | Reviewed: 01/25/2022 | Accept: 01/30/2022 | Published: 01/31/2022

Leidiene Ferreira Santos

ORCID: https://orcid.org/0000-0002-2969-6203

Universidade Federal do Tocantins, Brazil

E-mail: leidienesantos@mail.uft.edu.br

Vitória Fernandes Machado Nascimento

ORCID: https://orcid.org/0000-0002-5354-0428

Universidade Federal do Tocantins, Brazil E-mail: vivifnascimento@hotmail.com

Maitê da Veiga Feitoza Borges Silva

ORCID: https://orcid.org/0000-0001-6117-8775

Universidade Federal do Tocantins, Brazil

E-mail: maite.vfbs@gmail.com

Danielle Rosa Evangelista

ORCID: https://orcid.org/0000-0002-4472-2879

Universidade Federal do Tocantins, Brazil

E-mail: daniellerosa@mail.uft.edu.br

Erika Silva de Sá

ORCID: https://orcid.org/0000-0002-3026-6091

Universidade Federal do Goiás, Brazil

E-mail: erikadesa@mail.uft.edu.br

Juliana Bastoni da Silva

ORCID: https://orcid.org/0000-0002-6642-8910

Universidade Federal do Tocantins, Brazil

E-mail: juliana.bastoni@mail.uft.edu.br

Laiane de Paula Aquino Oliveira Carvalho

ORCID: https://orcid.org/0000-0001-5567-1803

Universidade Federal do Tocantins, Brazil

E-mail: laianedepaula@ hotmail.com

Raquel Cristina da Costa Brito

ORCID: https://orcid.org/0000-0003-4660-1971

Universidade Federal do Tocantins, Brazil

E-mail: raquelcristinabc@gmail.com

Sorlei Silva e Silva

ORCID: https://orcid.org/0000-0002-4916-8192

Universidade Federal do Tocantins, Brazil

E-mail: sorlei.silva@ifpa.edu.br

Daniela Pires Nunes

ORCID: https://orcid.org/0000-0002-4679-0373

Federal University of Campinas, Brazil

E-mail: dpnunes@unicamp.br

\begin{abstract}
The proper registration of cases of deaths and their analysis contribute to give visibility to the real gaps and demands of health services. The monitoring and the analysis of the Infant Mortality Rate (IMR) and its characteristics are paramount for the development of health policies and interventions aimed at the promotion and protection of child health. Thus, we aimed to characterize neonatal deaths recorded in Palmas, Tocantins, Brazil, in the period from 1999 to 2018, according to sex, weight and age of newborns, maternal age, and municipality of occurrence. There were 800 deaths of children aged up to 27 days of life in the municipality of Palmas from 1999 to 2018, with a statistical difference in the proportion of neonatal deaths according to the occurrence of the event, gender, and weight, with a higher proportion of early neonatal deaths when their occurrence was in Palmas. Although the municipality of Palmas has recorded advances in infant mortality indicators, specifically in the neonatal component, considering that Brazil
\end{abstract}


proposes to reduce newborn mortality to a maximum of five per thousand live births by 2030 , advances will be necessary to qualify perinatal care in the region in order to avoid preventable infant deaths. Thus, an urgent demand is the improvement of prenatal and maternal-infant care services in the municipality in order to favor maternal and infant indicators.

Keywords: Epidemiological monitoring; Infant mortality; Newborn.

\section{Resumo}

Registro adequado dos casos de óbitos e sua análise contribuem para dar visibilidade às reais lacunas e demandas dos serviços de saúde. O acompanhamento e análise da Taxa de Mortalidade Infantil (TMI) e suas características são primordiais para o desenvolvimento de políticas e intervenções de saúde voltadas para a promoção e proteção da saúde infantil. Assim, objetivou-se caracterizar os óbitos neonatais registrados em Palmas, Tocantins, Brasil, no período de 1999 a 2018, de acordo com sexo, peso e idade dos recém-nascidos, idade materna e município de ocorrência. Foram registrados 800 óbitos de crianças com idade de até 27 dias de vidas no município de Palmas, nos anos de 1999 a 2018, com diferença estatística na proporção de óbitos neonatais segundo a ocorrência do evento, sexo e peso, sendo maior proporção de óbitos neonatais precoces quando sua ocorrência foi em Palmas. Embora o município de Palmas tenha registrado avanços nos indicadores de mortalidade infantil, especificamente no componente neonatal, considerando que o Brasil se propõe a reduzir a mortalidade de recém-nascidos para no máximo 5 por mil nascidos vivos, até 2030, serão necessários avanços no sentido de qualificar a assistência perinatal na região, de modo a prevenir mortes infantis evitáveis. Assim, apresenta-se como demanda urgente, melhorar os serviços de assistência pré-natal e materno infantil no município, de modo a favorecer indicadores maternos e infantis.

Palavras-chave: Monitoramento epidemiológico; Mortalidade neonatal; Recém-nascido.

\section{Resumen}

Registro adecuado de los casos de óbitos y su análisis contribuyen a dar visibilidad a las reales lagunas y demandas de los servicios de salud. El seguimiento y análisis de la Tasa de Mortalidad Infantil (TMI) y sus características son primordiales para el desarrollo de políticas e intervenciones de salud orientadas a la promoción y protección de la salud infantil. Así, se objetivó caracterizar los óbitos neonatales registrados en Palmas, Tocantins, Brasil, en el período de 1999 a 2018, de acuerdo con sexo, peso y edad de los recién nacidos, edad materna y municipio de ocurrencia. Se registraron 800 muertes de niños con edad de hasta 27 días de vida en el municipio de Palmas, en los años de 1999 a 2018, con diferencia estadística en la proporción de óbitos neonatales según la ocurrencia del evento, sexo y peso, siendo mayor proporción de óbitos neonatales precoces cuando su ocurrencia fue en Palmas. Aunque el municipio de Palmas ha registrado avances en los indicadores de mortalidad infantil, específicamente en el componente neonatal, considerando que Brasil se propone reducir la mortalidad de recién nacidos a un máximo de 5 por mil nacidos vivos, Para 2030, será necesario avanzar hacia la cualificación de la asistencia perinatal en la región, a fin de prevenir muertes infantiles evitables. Así, se presenta como demanda urgente, mejorar los servicios de atención prenatal y materno infantil en el municipio, de modo a favorecer indicadores maternos e infantiles.

Palabas clave: Monitoreo epidemiológico; Mortalidad infantil; Recién nacido.

\section{Introduction}

In recent years, several countries have shown significant declines in the number of child deaths (Dandona et al., 2020; Burstein et at., 2019; Cha \& Jin, 2019; UNICEF, 2019). In the United States, for example, in 2018 the infant mortality rate decreased by $2.2 \%$, reaching 5.66 infant deaths per thousand live births (Murphy et al., 2021).

In Brazil, numerous strategies have been implemented with the aim of improving the quality of care provided to children and reducing morbidity and mortality in this population, such as the Policy for the Promotion of Breastfeeding, Milk Banks, the Child Friendly Hospital Initiative (IHAC), Integrated Management of Prevalent Childhood Illnesses (IMPCI) and Humanized Management of Low-birth-weight Newborns: Kangaroo-Mother Method (Brasil, 2002).

In this scenario, according to data from the Brazilian Institute of Geography and Statistics (IBGE), it is possible to observe a significant reduction in infant deaths, from 29 per thousand live births, in 2000, to 12.4 in 2018 (IBGE, 2019). It is noted that this result is directly related to the measures of improvements in health policies for child protection, the reduction of poverty, greater coverage, and better assistance and access to health mechanisms (Justino et al. 2019).

Despite advances in child health protection on the world stage, we must consider that mortality in this group is still high and its profile significantly influenced by socio-demographic inequalities. In 2018, 5.3 million children died before their fifth birthday. It is pointed out that the neonatal period, the first 28 days of life, represents the most vulnerable time for child 
survival, with a global mortality rate of 18 deaths per thousand live births. It is estimated that 2.5 million newborns died in the first month of life in 2018, approximately seven thousand deaths per day (UNICEF, 2019).

Research has shown that most neonatal deaths occur during the first three days of life, especially the first three days. Most deaths are related to asphyxia, prematurity, and congenital malformation. It is noteworthy that, in the first three days after birth, about 30\% of deaths occur in children under five years of age (Sankar et al., 2016).

On the national scene, according to a study conducted by França et al (2017), in 2015, mortality in children under one year of age accounted for about $90 \%$ of all deaths occurring in children up to five years of age. Of the deaths in children under one year of age, neonatal mortality accounted for about $70 \%$ of the cases, with most occurring on the first day of life.

When considering the above, it is presented, as a strategy, for reducing infant mortality, including the neonatal component, the implementation of public policies directed to the qualification of maternal and child health care, the organization of the perinatal care network, investments in physical and material resources, professional training and the implementation of practices based on scientific evidence, in order to improve the quality and safety of prenatal care, delivery and birth (Maia et al., 2020; Sleutjes et al., 2018).

Furthermore, the proper registration of cases of deaths and the analysis of this information are presented as resources capable of contributing to the reduction of neonatal mortality, in order to give visibility to the real gaps and demands of health services (Dias et al., 2017; Melo et al., 2017). It should be noted that the monitoring and the analysis of the Infant Mortality Rate (IMR) and its characteristics are essential for the development of health policies and interventions aimed at the promotion and protection of child health (UNICEF, 2019; Dias et al., 2017; Maranhão et al., 2012).

Thus, this research aimed to characterize the neonatal deaths recorded in Palmas, Tocantins, Brazil, in the period from 1999 to 2018, according to sex, weight and age of newborns, maternal age, and municipality of occurrence. It is noted that, for advances in the coming years, in relation to the reduction of neonatal mortality on the national scene, one must invest in improving the identification of the causes of death in children and evolve in regional and state analyses in order to verify weaknesses in child care and plan and implement strategies directed to the real demands of each context (Saltarelli et al., 2019).

\section{Methodology}

A time-series and documental-based research that analyzed the cases of neonatal deaths of mothers living in the municipality of Palmas, Tocantins, Brazil, notified from January 1999 to December 2018. The aforementioned municipality is located in the northern region of the country, with an area of 2,218,942 $\mathrm{km}^{2}$ and an estimated population of 299,127 people (IBGE, 2019).

The data was made available by the Department of Death Surveillance of the Municipal Health Secretariat, from the Mortality Information System (MIS) database, and tabulated through Tabwin. Later, they were imported and stored in a Microsoft Excel spreadsheet. It should be noted that at no time was there access to information that could identify the motherchild binomial. This stage of the research took place from January to July 2020.

It is noted that the neonatal death data for the year 2018 could still be updated during the year 2020, especially for deaths that occurred in other municipalities and/or States, since it is necessary to investigate this death for its notification.

Data analysis occurred from August to December 2020. To calculate the Infant Mortality Rates, neonatal component, we used calculation as indicated in the scientific literature (Brasil, 2009), in which the Early Neonatal Mortality Rate corresponds to the "number of deaths of children from zero to six complete days of life, per thousand live births, in the resident population in a given geographical space, in the year considered. And the Late Neonatal Mortality Rate was calculated considering the number of deaths of children from seven to 27 days of complete life (Brasil, 2009). 
Data regarding the number of live births to mothers residing in the municipality of Palmas were compiled from DATASUS. For live births that were born in one year and died in another (for example: born in 2017 and died in 2018), the year of birth was considered for the calculation of the Mortality Rate. The case was not excluded, only reassigned.

The confidence interval calculation was performed to make comparisons between two specific years. When the number of deaths was less than one hundred, a Poisson distribution was assumed, and to calculate the confidence interval, the coefficient was multiplied by the confidence factors of the upper and lower limits of the interval at the 95\% level (Mcdorman \& Atkinson, 1998).

For clinical and maternal characterization, Fisher's test and chi-square test were used, depending on the data. To verify the relationship between variables, Fisher's test was used, with a significance level of $5 \%(\mathrm{p}<0.05)$. The results were expressed in graphs and tables to facilitate visualization by the reader.

The variables used in this study were selected from the fields present in the Death Certificate standardized by the Ministry of Health, and represent aggregate measures that synthesize individual characteristics within each group (Bonita et al., 2010). The following were selected: gender, age and weight for the newborn, and age for the mother.

In the analysis and organization of the results, the variables were classified considering criteria from the scientific literature:

- Age of NB: based on the number of days from birth to death, using the classification established by the Ministry of Health (Brazil, 2009), which corresponds to "early neonatal mortality", that in which the death occurs between zero to six days of life, and "late neonatal mortality", that in which the death occurred between seven to 27 days of life;

- NB's Sex: was classified as "Female" or "Male;

- NB's weight: "NB of adequate weight for life", when above 2500 grams at birth; "Low-birth weight NB", when 1500 to 2499 grams at birth, and "Extremely low-birth weight NB", when less than 1499 grams at birth (Brasil, 2009);

- Maternal age: as suggested in the study by Bouzas et al. (2014), "early maternal age" is delimited when the woman presents from ten to 14 years; "adult maternal age", from 20 to 34 years and "late maternal age", above 35 years.

The records of neonatal deaths that occurred as of 1999 were included, the period in which the notifications in the city from mothers residing in Palmas began, regardless of the place of occurrence of the death. The exclusion criterion was not having the date of birth of the child on the form. When considering the criteria cited, there was no exclusion.

This research complied with the precepts of the National Health Council Resolution (NHC) No. 466/12, and was approved by the Municipal Health Secretariat of Palmas and by the Ethics in Human Research Committee, CAAE 07887019.9.0000.5516.

\section{Results}

In total, in the municipality of Palmas, from 1999 to 2018, 800 neonatal deaths were notified. It is recorded that there was a higher percentage of early neonatal deaths (73.25\%). According to the place of occurrence, there was a statistical difference in the proportion of neonatal deaths according to the occurrence of the event (Figure 1). 
Figure 1. Proportion of early and late neonatal deaths, in the period from 1999 to 2018, occurring in the municipality of Palmas and other municipalities in the State of Tocantins. Palmas, TO, Brazil, $2020(n=800)$.

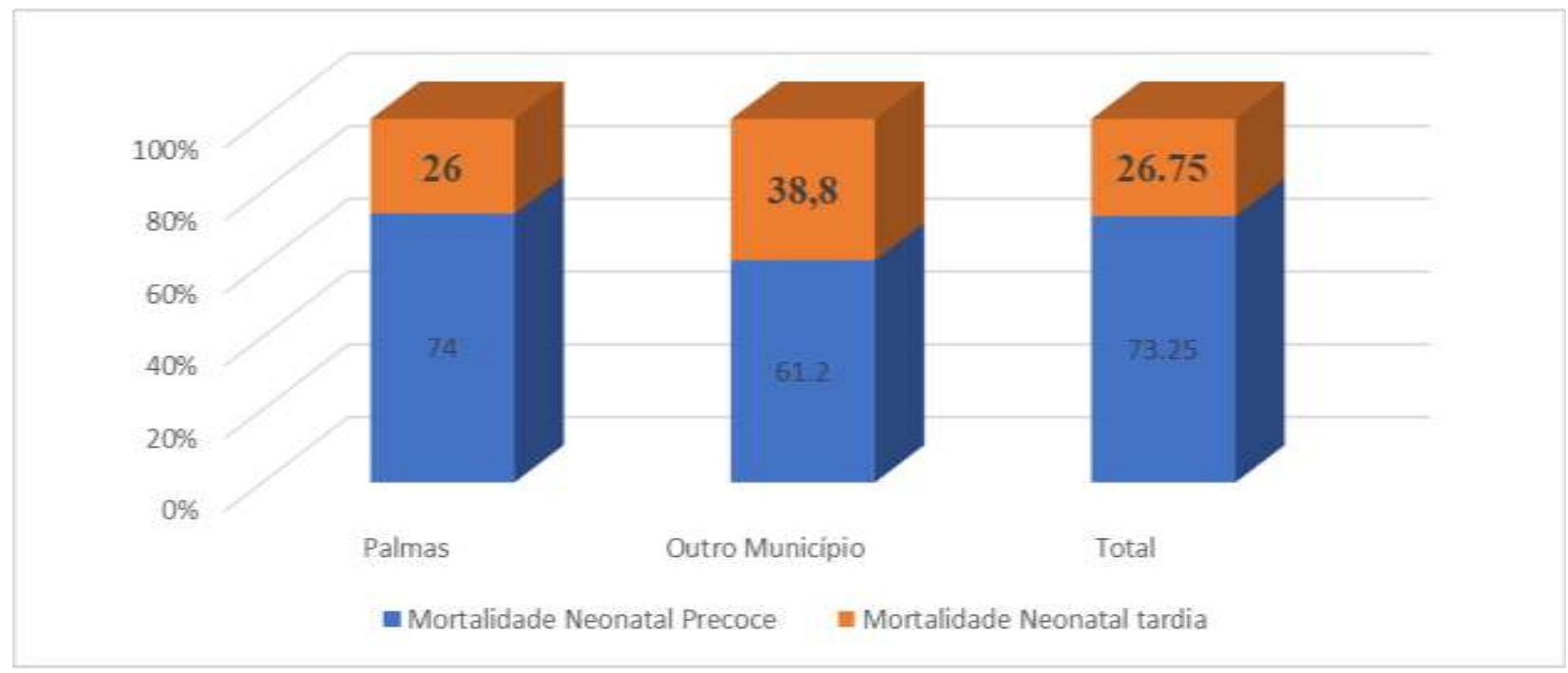

Source: MIS (2019). (Data updated in 09/2019). p=0.05. Figure elaborated by Elaborated by the authors, Palmas-TO, Brasil, 2021.

It is possible to notice a higher proportion of early neonatal deaths when their occurrence was in Palmas (556; 74.0\%). This fact may be related to birth complications and/or congenital malformations.

Among the early neonatal deaths, when compared to the other municipalities, Palmas presented a higher proportion in relation to sex and weight (Table 1). 
Table 1. Absolute and relative number of early and late neonatal deaths, that occurred in the period from 1999 to 2018 , according to municipality, sex and weight of the NB and maternal age. Palmas/TO, Brazil, $2020(\mathrm{n}=800)$.

\begin{tabular}{|c|c|c|c|}
\hline \multirow[t]{2}{*}{ Variables } & \multicolumn{2}{|c|}{ Municipality } & \multirow[b]{2}{*}{$p$} \\
\hline & $\begin{array}{c}\text { Palmas } \\
\mathrm{n}(\%)\end{array}$ & $\begin{array}{l}\text { Other } \\
\mathrm{n}(\%)\end{array}$ & \\
\hline \multicolumn{4}{|c|}{ Early Neonatal Death } \\
\hline Newborn's sex $(n=573)$ & & & 0.022 \\
\hline Male & $301(76.7)$ & 23 & \\
\hline Female & 242 & 7 & \\
\hline Weight $(n=568)$ & & & 0.023 \\
\hline$<1500 \mathrm{~g}$ & 323 & 7 & \\
\hline 1500 to $2499 \mathrm{~g}$ & 92 & 7 & \\
\hline$>=2500 \mathrm{~g}$ & 130 & 9 & \\
\hline Mother's age $(n=538)$ & & & 0.229 \\
\hline 10 to 14 years & 9 & 0 & \\
\hline 15 to 19 years & 122 & 2 & \\
\hline 20 to 34 years & 338 & 16 & \\
\hline 35 years or more & 47 & 4 & \\
\hline \multicolumn{4}{|c|}{ Late Neonatal Death } \\
\hline Newborn's sex $(n=213)$ & & & 0.544 \\
\hline Male & 106 & 9 & \\
\hline Female & 88 & 10 & \\
\hline \multicolumn{4}{|l|}{ Weight $(n=200)$} \\
\hline$<1500 \mathrm{~g}$ & 104 & 2 & 0.059 \\
\hline 1500 to $2499 \mathrm{~g}$ & 41 & 5 & \\
\hline$>=2500 \mathrm{~g}$ & 45 & 3 & \\
\hline Mother's age $(n=194)$ & & & 0.626 \\
\hline 10 to 14 years & 45 & 2 & \\
\hline 15 to 19 years & 120 & 6 & \\
\hline 20 to 34 years & 19 & 2 & \\
\hline 35 years or more & 184 & 10 & \\
\hline
\end{tabular}

Source: Elaborated by the authors, Palmas-TO, Brasil (2021).

It is possible to observe a higher proportion of deaths of male neonates (44.6\%) and weighing less than $1500 \mathrm{~g}$ $(59.3 \%)$, in the city of Palmas. Regarding late neonatal death, there were no statistical differences between the place of occurrence of death, sex and weight of the neonate and age of the mother.

\section{Discussion}

Despite numerous countries showing great progress in reducing the number of child deaths (Cha \& Jin, 2019), such as India, where the under-five mortality rate fell by $49 \%$ and the neonatal mortality rate by $38 \%$ between 2000 and 2017 (Dandona et al., 2020), child death from preventable causes is still a public health problem that plagues many parts of the world (UNICEF, 2019).

In the municipality of Palmas, 800 neonatal deaths were identified in the 20 -year period and, as in many other countries (Martin et al., 2021; Murphy et al., 2021), the significant reduction in neonatal mortality is still presented as an unmet challenge.

In Georgia, for example, the perinatal mortality rate remained high in 2017. During this period, 489 stillbirths and 238 early neonatal deaths were recorded, resulting in a perinatal mortality rate of 13.6 per thousand births. About $80 \%$ of the stillbirths had unknown cause of death, and most deaths occurred before the onset of labor (85\%). Prematurity (58\%) and congenital malformations (23\%) were the main causes of early neonatal loss, and $70 \%$ of these deaths occurred after the first day of life (Manjavidze et al., 2019). 
As evidenced in this study, in the global scenario, there is a predominance of premature deaths, in the neonatal component (UNICEF, 2019). In the United States, in turn, the preterm birth rate increased for the fifth consecutive year from 2015 to 2019 (Martin et al., 2021). It is noteworthy that preterm birth presents as a risk factor for respiratory complications at birth, and corroborates hypoglycemia, sepsis, and food intolerance (Zhang et al., 2021).

Most $(104 ; 60.5 \%)$ of the admissions to a Neonatal Intensive Care Unit, located in the city of Palmas, in the period of one year, were due to prematurity. Cardiopathies, congenital malformation, sepsis, and syphilis were also conditions that led the child to depend on intensive care (Santos et al., 2016).

Research has shown that surgical delivery, the maternal age below 20 years, low birth weight babies, and short birth intervals ( $\leq 2$ years) also represent a higher risk for neonatal death and the death of children under one year of age (Ogbo et al., 2019). In the national scenario, the absence of a partner, maternal age $\geq 35$ years, male gender, multiple gestation, inadequate and absent prenatal care, presence of intercurrences during pregnancy, congenital malformation, Apgar $<7$ in the fifth minute, low and very low birth weight, gestational age $\leq 37$ weeks, and cesarean delivery are presented as risk factors for neonatal mortality (Veloso et al., 2019). In Japan, in which the top five causes of death for neonates were congenital hypoplasia, trisomy, low birth weight, and severe neonatal asphyxia (Tashiro et al., 2019).

Regarding prematurely born babies, a research indicated that gestational age at birth (higher risk for lower gestational age), gender (male), delivery route (cesarean), premature rupture of membranes, gestational diabetes, neonatal asphyxia and father's smoking addiction (maternal exposure to smoke during pregnancy) are important risk factors for Respiratory Distress Syndrome (RDS) (Xu \& Xu, 2021; Yoon et al., 2021).

Furthermore, infants born prematurely may show significantly lower performance than to the full-term children, especially in the areas of motor development, cognition, and socialization (Rodrigues \& Bolsoni-Silva, 2011). Low birth weight is also associated with delayed child development (Yoon et al., 2021).

In this sense, several measures should be adopted in order to prevent prematurity, especially to qualify and optimize prenatal care (Brito et al., 2021). As a strategy to protect the health of premature newborns, it is recommended the implementation of interventions, still in the ICU, that guide, encourage, and support mothers regarding breastfeeding, because strategies of this type have significant effects on the practice and on the breastfeeding continuation rate and breastfeeding selfefficacy (Kang et al., 2021).

It should be noted that the findings of this research showed that there is statistical difference in the proportion of neonatal deaths according to the occurrence of the event, and the highest proportion of early neonatal deaths occurred in Palmas $(556 ; 74.0 \%)$. This fact indicates the urgent need for interventions capable of protecting the health and life of neonates (Gama et al., 2021). In this sense, the literature presents, as a strategy for the protection and promotion of child health, the evaluation of the child in his first week of life, an appropriate period for health professionals to guide families on immunization, neonatal screening, establishment of a support network, early diagnosis of physiological changes, identification and action in difficulties related to breastfeeding and general care (Soares et al., 2020).

It is essential to qualify Primary Health Care professionals, aiming at reducing infant mortality, in order to raise their awareness about the importance of proper surveillance of child development, contributing to provide children and families with quality care (Vieira et al., 2019; Lucena et al., 2018). Articulating the relationships between support and health care sectors and promoting the exchange of actions and inter-sectorality are also extremely important, because, in addition to corroborating comprehensive care to the NB and families, especially those who depend on social policies, requiring state equipment and other initiatives, they also favor better indicators of maternal and child health (Furtado et al., 2010).

Thus, the relevance of actions aimed at improving the knowledge and skills of health professionals is presented (Santos et al., 2020) in order to promote the proper implementation of the pediatric physical examination and the satisfactory 
assessment and monitoring of child growth and development (Gaíva et al., 2018). It should be noted that improving technical and scientific knowledge is a key aspect to determine which interventions are necessary at the time of the child consultation (Hanzen et al., 2019).

When considering that situations of violence during pregnancy are also risk factors for the life of the newborn, since this situation is associated with adverse health outcomes for the woman-child binomial, it is suggested the need for prevention of intimate partner violence and the integration of screening and treatment of intimate partner violence in prenatal care, reproductive health services and maternal and child health programs and services to identify and treat women at risk (Miller \& Contreras-Urbina, 2021).

In conclusion, the importance of this research is highlighted, since knowing the distribution of causes of death and risk factors in each place, as well as the socio-demographic aspects that influence them, corroborates a more comprehensive and consolidated understanding of these data, implementing policies aimed at combating inequalities in infant mortality, as well as providing valuable information to improve child health indicators (Dandona et al., 2020; Tashiro et al., 2019).

A limitation of this research is the absence of maternal variables that could be associated with the outcome and thus allow better visibility and understanding of indicators related to neonatal mortality in the municipality.

\section{Conclusion}

A total of 800 deaths of children aged up to 27 days of life were recorded in the municipality of Palmas in the years 1999 to 2018, with a statistical difference in the proportion of neonatal deaths according to the occurrence of the event, sex and weight, with a higher proportion of early neonatal deaths when their occurrence was in Palmas.

This unprecedented study, the first to analyze data on neonatal deaths in the capital of the state of Tocantins, was made possible by the efforts of local researchers with a view to contributing to the visibility of child health indicators in the country and the region.

Although the municipality of Palmas has recorded advances in infant mortality indicators, specifically in the neonatal component, considering that Brazil proposes to reduce newborn mortality to a maximum of five per thousand live births by 2030, advances will be necessary to qualify perinatal care in the region in order to prevent prevent preventable infant deaths. Thus, an urgent demand is the improvement of prenatal and maternal-infant care services in the municipality in order to favor maternal and infant indicators.

In view of the results and the discussions presented, it can be concluded that it is essential to invest in research that evaluates the quality of prenatal care, as well as the conditions of assistance to delivery and immediate care at birth. In addition to new studies to identify the causes of these deaths and the investment in the training of professionals to complete the DC (Death Certificate), in order to intensify the declining trend of neonatal mortality in this capital.

\section{Acknowledgments}

Thanks to the Federal University of Tocantins and the Postgraduate Program in Teaching in Science and Health (UFT), for supporting the development of this research.

Research developed by the Group of Studies and Research in Child Health at the Federal University of Tocantins (GEPESC-UFT)

\section{References}

Bonita, R., Beaglehole, R. \& Kjellström, T. (2010). Epidemiologia básica. (2a ed.), Santos 
Bouzas, I. C. S., Cader, D. A. \& Leão, L. (2014) Gravidez na adolescência: uma revisão sistemática do impacto da idade materna nas complicações clínicas, obstétricas e neonatais na primeira fase da adolescência. Adolesc. Saude, 11(3), 7-21.

Brasil. (2009). Manual de vigilância do óbito infantil e fetal e do comitê de prevenção do óbito infantil e fetal. Secretaria de Vigilância em Saúde. Departamento de Análise de Situação de Saúde. Brasília: Ministério da Saúde. https://bvsms.saude.gov.br/bvs/publicacoes/manual_obito_infantil_fetal_2ed.pdf

Brasil. (2002). Programas e Projetos da Saúde da Criança: responsabilidades compartilhadas em benefício das crianças brasileiras. Rev. Bras. Saude Mater. Infant. 2(2), 193-200. https://doi.org/10.1590/S1519-38292002000200013

Brito, L. C. S. et al. (2021). Epidemiological aspects of child mortality. Rev. Enferm. UFPE on line: 15(1), 1-12. https://doi.org/10.5205/19818963.2021 .244656

Burstein, R. et al. (2019). Mapping 123 million neonatal, infant and child deaths between 2000 and 2017. Nature, 574(1), 353-358. https://doi.org/10.1038/s41586-019-1545-0

Cha, S. \& Jin, Y. (2019). Have inequalities in all-cause and cause-specific child mortality between countries declined across the world? International Journal for Equity in Health. 19(1), 1-13. https://doi.org/10.1186/s12939-019-1102-3

Dandona, R. et al. (2020). Subnational mapping of under-5 and neonatal mortality trends in India: the Global Burden of Disease Study 2000-17. The Lancet, 395(10237), 1640-1658. https://doi.org/10.1016/S0140-6736(20)30471-2

Dias, B. A. S., Santos, E. T. N \& Andrade, M. A. C. (2017). Classification systems for avoidability of infant deaths: different methods, different repercussions? Cad. Saúde Pública. 33(5), 1-15. https://doi.org/10.1590/0102-311X00125916

França, E. B. et al. (2017). Leading causes of child mortality in Brazil, in 1990 and 2015: estimates from the Global Burden of Disease study. Rev Bras de Epidemiol. 20(1), p.46-60. https://doi.org/10.1590/1980-5497201700050005

Furtado, M. C. C. et al. (2010). The evaluation of newborn care in the relationship between maternity hospital and basic health net. Rev. Eletr. Enf. 12(4), 6406. https://doi.org/10.5216/ree.v12i4.7625

Gaíva, M. A. M., Monteschio, C. A. C., Moreira, M. D. A \& Salge, A. K. M. (2018). Child growth and development assessment in nursing consultation. Av. enferm. 36(1) 9-21. https://doi.org/10.15446/av.enferm.v36n1.62150

Gama, S. G. N., Thomaz, E. B. A. F. \& Bittencourt, S. D. A. (2021). Advances and challenges in healthcare for delivery and childbirth in the Unified Health System (SUS): the role of Rede Cegonha. Ciênc. saúde coletiva, 26(3) https://doi.org/10.1590/1413-81232021262.41702020

Hanzen, I. P., Zanotelli, S. S., \& Zanatta, E. A. (2019). Diagnostics, interventions and nursing results to subsidy the nursing consultation of the child. Enferm Foco., 10(7), 16-21. https://doi.org/10.21675/2357-707X.2019.v10.n7.2683

Instituto Brasileiro de Geografia e Estatística. (IBGE). (2019). Panorama Brasil. Palmas. Rio de Janeiro: IBGE, 2019.

Justino, D. C. P., Lopes, M. S., Santos, C. D. C \& Andrade. F. B. (2019). Historical evaluation of children's public health policies in Brazil: integrative review. Revista Ciência Plural, 5(1), 71-88, 2019. https://doi.org/10.21680/2446-7286.2019v5n1ID17946

Kang, J. H., Son, H., Byun, S. Y, \& Han G. (2021). Effect of Direct Breastfeeding Program for Premature Infants in Neonatal Intensive Care Unit. J Korean Acad Nurs. 51(1), 119-132. https://doi.org/10.4040/jkan.20240

Lucena, D. B. A. et al. (2018). First week of integral health for the newborn: nursing actions of the Family Health Strategy. Rev Gaúcha Enferm. 39(e20170068), 1-8. https://doi.org/10.1590/1983-1447.2018.2017-0068

Maia, L. T. S., Souza, W. V. \& Mendes, A. C. G. (2020). Individual and contextual determinants of infant mortality in Brazilian state capitals: a multilevel approach. Cad. Saúde Pública. 36(2), 1-19, 2020. https://doi.org/10.1590/0102-311X00057519

Manjavidze, T., Rylander, C., Skjeldestad, F. C., Kazakhashvili, N \& Anda, E. E. (2019). Incidenceand Causes of Perinatal Mortality in Georgia. J EpidemiolGlob Health, 9(3), 163-168. https://doi.org/10.2991/jegh.k.190818.001

Maranhão, A. G. K., Nogales, V. A. M., Lopes, D. \& Elizabeth, F. (2011). Mortalidade infantil no Brasil: tendências, componentes e causas de morte no período de 2000 a 2010. In: Brasil. Ministério da Saúde. Saúde Brasil 2011: uma análise da situação de saúde e da agenda nacional e internacional de prioridades em saúde. Brasília: Ministério da Saúde. http://portalsaude.saude.gov.br/portalsaude/arquivos/pdf/2013/Fev/21/saudebrasi12011_parte1_cap6.pdf

Martin, A. J. et al. (2021). Nascimentos: dados finais para 2019. Natl Vital Stat Re70(2), 1-51. https://www.cdc.gov/nchs/data/nvsr/nvsr70/nvsr70-02-508.pdf

Mcdorman, M. F. \& Atkinson, J. O. (1998). Estatísticas de mortalidade infantil do conjunto de dados de nascimentos / óbitos vinculados - dados do período de 1995. Mon Vital Stat, 26(46), 1-22. https://pubmed.ncbi.nlm.nih.gov/9524421/

Melo, C. M., Aquino, I. S., Soares, M. Q. \& Bevilacqua, D. (2017). Death surveillance as an indicator of the quality of health care for women and children Ciênc. saúde colet. 22 (10), 3457-3465. https://doi.org/10.1590/1413-812320172210.19652017 
Miller, L. \& Contreras-Urbina, M. (2021). Exploring the determinants and outcomes of intimate partner violence during pregnancy for Guyanese women: results from a nationally representative cross-sectional household survey. Ver Panam Salud Publica. 45(3), 1-11. https://doi.org/10.26633/RPSP.2021.6

Murphy, S. L. et al. (2021). Deaths: Final Data for 2018. Natl Vital Stat Re69(13), 1-83. https://www.cdc.gov/nchs/data/nvsr/nvsr69/nvsr69-13-508.pdf

Ogbo, F. A. et al. (2019) Determinantsoftrends in neonatal, post-neonatal, infant, childandunder-fivemortalities in Tanzaniafrom 2004 to 2016. BMC Public Health. 19(1) 1-12, 2019. https://doi.org/10.1186/s12889-019-7547-x

Rodrigues, O. M. R. \& Bolsoni-Silva, A, T. (2011). Effects of the prematurity on the development of lactentes. Rev. Bras. Cresc. E Desenv. Hum, 21(1), 111121. http://pepsic.bvsalud.org/scielo.php?script=sci_arttext\&pid=S0104-12822011000100011\&lng=pt\&tlng=pt

Saltarelli, R. M. F., Prado, R. R., Monteiro, R. A. \& Malta, D. C. (2019). Trend in mortality from preventable causes in children: contributions to the evaluation of the performance of public health services in the Southeast Region of Brazil. Rev. bras. epidemiol. 22(1) 1-15. https://doi.org/10.1590/1980549720190020

Sankar, M. J. et al. (2016). When do newborns die? A systematic review of timing of overall and cause-specific neonatal deaths in developing countries. Journal of Perinatology. 36(1), 1-11. https://doi.org/10.1038/jp.2016.27

Santos, L. F. et al. (2016). epidemiological profile of hospitalizations in a neonatal intensive care unit. Rev enferm UFPE on line. 10(8), 2965-73. https://doi.org/10.5205/1981-8963-v10i8a11366p2965-2973-2016

Santos, L. F. et al. (2020). Physical examination in nurses' hospital practice. Research, Society and Development, 9(7), 1-15. https://doi.org/10.33448/rsdv9i7.3794

Sleutjes, F. C. M., Parada, C, M, G, L., Carvalhaes, M. A. B. L. \& Temer, M. J. (2018). Risk factors for neonatal death in an inland region in the State of São Paulo Brazil. 23(8), 2713-2720. https://doi.org/10.1590/1413-81232018238.15142016

Soares, A. R et al. (2020). Ideal time for home visits to newborns: an integrative review. Ciênc. saúde coletiva. 25(8), 3311-3320. https://doi.org/10.1590/141381232020258.25492018

Tashiro, A., Yoshida, H. \& Okamoto, E. (2019). Infant, neonatal, and post neonatal mortality trends in a disaster region and in Japan, 2002-2012. a multiattribute compositio nalstudy. BMC Public Health. 19(1085), 1-13. https://doi.org/10.1186/s12889-019-7443-4

United Nations Children's Fund (UNICEF). (2019). Levels \& Trends in Child Mortality: Report 2019, Estimates developed by the United Nations Interagency Group for Child Mortality Estimation. New York: UNIGME. https://www.unicef.org/media/60561/file/UN-IGME-child-mortality-report-2019.pdf

Veloso, F. C. S. et al. (2019) Analysisof neonatal mortalityriskfactors in Brazil: a systematicreviewand meta-analysisofobservationalstudies. J Pediatr. 95(5), 519-530. https://doi.org/10.1016/j.jped.2018.12.014

Vieira, D, S. et al. (2019). Work process of nurses in child development surveillance. Rev Min Enferm. 23(e-124), 1-7. http://dx.doi.org/10.5935/14152762.20190090

Xu, H. \& Xu, (2021). Efficacy analysis of diferente pulmonar surfactants in premature infants with respiratory distress syndrome. "Zhonghua Wei Zhong Bing Ji Jiи Yi Хие"[jour]. 33(2): 174-179. https://doi.org/10.3760/cma.j.cn121430-20201009-00660

Yoon, S. J. et al. (2021) Identification of Growth Patterns in Low Birth Weight Infants from Birth to 5 Years of Age: Nationwide Korean Cohort Study. Int. J. Environ. Res. Public Health. 18(3), 1-11. https://doi.org/10.3390/ijerph18031206

Zhang, Y. M., Shao, S. M., Zhang, X. R., Liu, J. \& Zeng, C.M. (2021). [Perinatal conditions of late preterm twins versus early term twins]. Zhongguo Dang dai er ke za zhi $=$ Chinese Journal of Contemporary Pediatrics. 23(3), 242-247. https://doi.org/10.7499/j.issn.1008-8830.2011126 